UDC $621.318 .38: 621.039 .6: 531.76 .082 .5$

\title{
レーザ核融合用磁気ペレットインジェクタの開発 （I．二段加速）
}

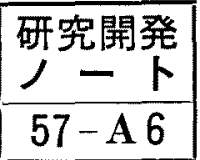

正阪上幸 男 (岐阜大)
非会員 間 淵 義 宏 (岐卓大)

レーザ核融合を実理するには，然料となるぺレット をレーザ集束点に位管精度良く，加つ周期性を持たせ

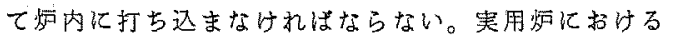
予測では直径 $6 \mathrm{~mm}$ のペレットを炉半径 $5 \mathrm{~m}$ の炉心 飞 1 10 Hz の周期で打ち迅むとと，その之きの位置 精度は直径の $1 / 100$ 以内で速度 $15 \mathrm{~m} / \mathrm{s}$ 以上が必要で

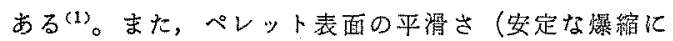
必要)を保ったり多量のペレット(105/日) を扱うた め非接触制䧃が要求される。しれらの要求を满たすぺ レットインシェクタば，現在世界的化も十分な研究が 行なるれていない。乙てで著者らは，上記条件を満た す非接触制御として，無带蟹粒子を大きな力で駆動し 得る磁気力を使ったペレットインジェクタの開発に着 手したので報告する。

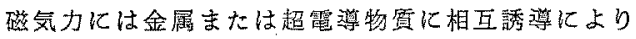
筐磁力を作用させるものと磁性体に磁界のとう配力 (グレーディエント力)を作用させるすのがある。後者 の利用としては、ソレノイドコイル開口端の磁気こう 配を利用して鉄球をコイル外へ飛しょうさせる方法が 山田氏らによって壀告されている(2)。本研究ではこの 技術を利用して多段加速を試み，その手初めとして本 埌告では二段加速の実験結果について述べる。

図1飞実験装䈯を示す。一段目，二段目のコイルの 各々に结放電用としゃ断用の二つの SCR 設けた。 各コイルの通電時間をあらかじめ設定(ハードタイマ) して怙き，コイルの入力端で鉄球を加速し得るように しだ゙。各コイルの放篦用 SCR のゲートKマイクロ コンピュータの制微信（二つの信号間をンフトタイ マで調整）をえた。图に示すように，鉄球（面径 $9.5 \mathrm{~mm}$, 留聂 $3.53 \mathrm{~g})$ が二段目のコイルを飛び出し たところに He-Ne レーザ, 光检知器（ホトトランジ スタ) およびストレージスコープを配遗し速度を测定 した。図2はソフトタイマの設定時間 $t$ を横韩に, 鉄 球の速度の実测值を示したもので，二段目コイルの加 速効果を示す毛のである。すなわち，t=0で $v=2.4$ $\mathrm{m} / \mathrm{s}$ を得ている。これは一弫目コイルのみの寄与によ る速度を示す。 $t=16 \mathrm{~ms}$ で二段目コイルの加速が有効

Development of a Magnetic Pellet Injector for Iaser Fusion I. Two Stage Acceleration. By Yukio Sakagami, Member \& Yoshihiro Mabuchi, Non-member (Faculty of Engineering, Gïu University).

阪上幸男: 正員, 岐帛大学工学部笔気工学科

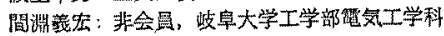

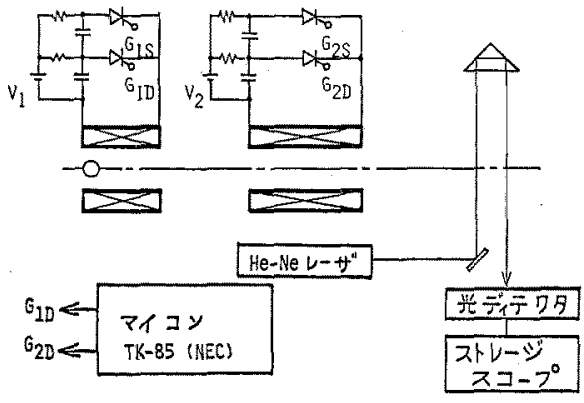

図 1 磁気ペレットインジェタタの 二段加速荠置の概要

Fig. 1. Schematic diagram of two stage acceleration of a magnetic pellet injector.

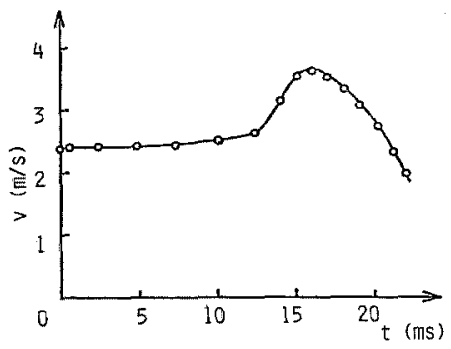

困はンフトタイマ都定時間に対するぺレット速度を示す

图 2 二段加速を示す实駰結果

Fig. 2. Experiment to demonstrate two stage acceleration.

に㗢き $3.6 \mathrm{~m} / \mathrm{s}$ となっている。

レーザ核融合ペレットの多尿篟造の一尿磁性体尿 よするととにより，本方式がレーザ核融合へ適用でき ると思われる。今後加速の最適設計索推し進めていく つもりである。

最後に, 研究の指尊 (大阪大学山中干代衛教授),

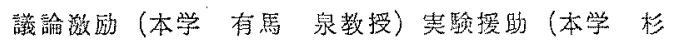
江暑氏)に対し感辢する。

(昭和 57 年 4 月 26 日受付)

$$
\text { 文、献 }
$$

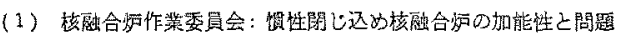
点, P. 97 (昭 54) 名古屋大学ブラズマ研究所，核融合研究 企画情報センタ

(2) 山田・大谷・杉田: 霆気学会磁気応用研資 AM-77-12(昭 52)

(3) 阪上・間洲：レーザ研究，10，318(昭 57) 